\title{
Spawanie tłoczyska siłowników hydraulicznych
}

\section{Welding piston rod of hydraulic cylinders}

\section{Streszczenie}

W artykule podjęto problem spawania tłoczysk siłowników hydraulicznych pracujących pod obciążeniami statycznymi, zmęczeniowymi i udarowymi. Omówiono badania niszczące wykonane na różnoimiennych złączach próbnych. Badania przewidziane w procedurze uznawania technologii spawania wykonano na czterech złączach próbnych, różniących się rodzajem użytego drutu oraz zastosowaniem bądź nie grzania wstępnego podczas spawania. Zauważono, że z powodu warunków eksploatacyjnych tłoczyska wymagają bardziej wszechstronnych badań od tych, które zalecają obowiązujące normy i przepisy towarzystw klasyfikacyjnych. Na przykład badań dostarczających szerszej informacji o wytrzymałości zmęczeniowej tłoczysk. Wykonano obliczenia numeryczne rozkładu naprężeń w złączu próbnym oraz wstępne badania zmęczeniowe próbek pobranych z tych złączy.

\section{Abstract}

The article discusses the problem of welding piston rod hydraulic cylinders working under static loads, fatigue and impact. Discusses destructive testing performed on dissimilar joints. The tests provided the recognition procedure of welding joints was performed in four joints, which differ in the type of wire used and the use or not preheating during welding. It was noted that due to the piston operating conditions require a more comprehensive study of the stars, that the applicable standards and regulations of classification societies. For example, studies that provide greater information on the fatigue strength piston rods. Performed numerical calculations of stress distribution in the joint trial and preliminary fatigue tests of samples taken of these joints.

\section{Wstęp}

W celu jednoczesnego spełnienia wymagań technicznych i ekonomicznych ucha tłoczysk i tłoczyska siłowników hydraulicznych wykonuje się z różnych materiałów. O wyborze materiału na ucha decyduje przede wszystkim jego wytrzymałość doraźna i zmęczeniowa, a materiały na tłoczyska muszą dodatkowo mieć wysoką odporność na ścieranie lub umożliwiać pokrycie ich powłokami przeciwścieralnymi o małej chropowatości. Wymagana wysoka wytrzymałość doraźna i zmęczeniowa elementów siłowników hydraulicznych podyktowana jest ich warunkami pracy. Siłowniki pracują pod obciążeniami statycznymi, zmęczeniowymi i udarowymi, nierzadko w środowisku o dużym zapyleniu, w temperaturze dodatniej oraz ujemnej. Ucha z tłoczyskami łączy się najczęściej za pomocą gwintów [1]. Zaletą rozłącznego połączenia gwintowego jest możliwość wymiany ucha o określonej postaci na inne,

Dr inż. Michał Kawiak - Zachodniopomorski Uniwersytet Technologiczny w Szczecinie. co zwiększa zakres zastosowań danego typu siłownika. Połączenia gwintowe mają również wady - poszczególne zwoje gwintów nie są równomiernie obciążone. $\mathrm{Na}$ początkowych zwojach występuje znaczne spiętrzenie naprężeń zwiększające prawdopodobieństwo powstania złomu zmęczeniowego [2]. Dodatkowo połączenia gwintowe charakteryzują się podatnością do samoodkręcania pod wpływem zmiennych obciążeń.

W ofertach niektórych firm wytwarzających siłowniki hydrauliczne można znaleźć obok tłoczysk z połączeniami gwintowymi również tłoczyska spawane $[3,4]$. Materiały zastosowane na tłoczyska spawane powinny mieć wszystkie pożądane cechy materiałów stosowanych na tłoczyska z połączeniami gwintowymi oraz dodatkowo charakteryzować się dobrą spawalnością. Uniwersalność siłowników hydraulicznych, w których zastosowano tłoczyska spawane, jest mniejsza niż siłowników $z$ tłoczyskami z połączeniami gwintowymi. Nierozłączne połączenie spawane tłoczyska wyklucza możliwość zamiany ucha na inne. Zaletą tłoczysk spawanych jest niższy koszt ich produkcji w porównaniu do kosztu produkcji tłoczysk z gwintem. 
Firmy, planując rozpoczęcie produkcji tłoczysk spawanych lub rozszerzenie asortymentu produkowanych tłoczysk, przeprowadzają procedurę uznania technologii ich spawania. W praktyce jest często tak, że przed rozpoczęciem wspomnianej procedury wykonywane są badania rozpoznawcze, mające na celu wcześniejsze wykrycie możliwych wad badanych złączy i wprowadzenie niezbędnych korekt we wstępnej instrukcji technologicznej spawania. W ten sposób zwiększa się prawdopodobieństwo, że podczas procedury uznaniowej badania będą się kończyć pozytywnie. Taki właśnie cel miały badania omówione w niniejszym artykule. Złącza próbne tłoczysk, omówione poniżej, różnią się kształtem od złączy opisanych w normie PN-EN ISO 15614-1 [5]. Są to złącza nietypowe, podobne tylko $w$ małym stopniu do złączy próbnych z rur ze spoiną czołową. Na próbnych złączach tłoczysk, spawanych drutem zasadowym lub rutylowym z grzaniem lub bez grzania wstępnego, wykonano standardowe badania niszczące przewidziane $w$ procedurze uznawania technologii spawania i dodatkowo wstępne badania zmęczeniowe oraz obliczenia rozkładu naprężeń w złączu.

\section{Złącze próbne tłoczyska}

Na rysunku 1 pokazano przedmiotowe tłoczysko spawane. Podano na nim zgodnie z rysunkiem wykonawczym: główne wymiary tłoczyska, materiały z których wykonano tłoczysko, oraz sposób połączenia jego części. Na podstawie wstępnej instrukcji technologicznej spawania wykonano cztery złącza

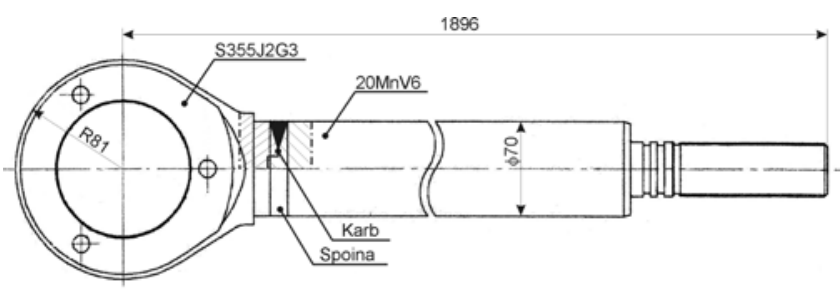

Rys. 1. Tłoczysko spawane

Fig. 1. Welded piston rod

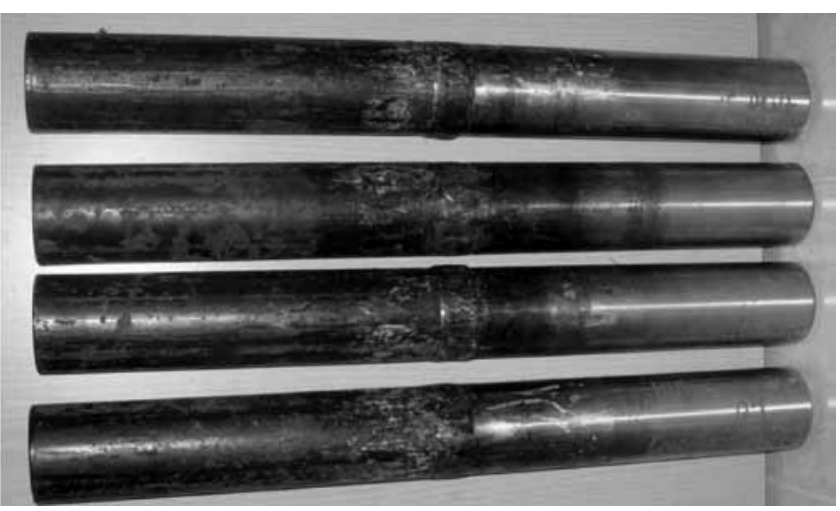

Rys. 2. Złącza próbne tłoczyska

Fig. 2. Test joints of piston rod próbne pokazane na rysunku 2 . Spawano je metoda 136, z prętów o średnicy $70 \mathrm{~mm}$, ze stali S355J2G3 (ucho tłoczyska) i 20MnV6 (część tłoczyska, do której mocowany jest tłok). Składy chemiczne i właściwości mechaniczne materiałów podstawowych oraz dodatkowych podano w tablicy I. Złącza spawano drutem Hyundai 70ML, używając gazu osłonowego M21. Dwa złącza próbne pospawano drutem zasadowym o średnicy $1 \mathrm{~mm}$, a kolejne dwa drutem rutylowym o średnicy $1,2 \mathrm{~mm}$. W przypadku jednego złącza spawanego drutem zasadowym i jednego spawanego drutem rutylowym zastosowano grzanie wstępne. Pozostałe dwa złącza pospawano bez grzania wstępnego. W celu zapewnienia rozkładu ciepła zbliżonego do tego, jaki występuje w rzeczywistych tłoczyskach podczas ich spawania, złącza próbne wykonano z prętów o odpowiednio dużej długości (300 mm). Pozostałe wymiary elementów złączy próbnych podano na rysunku 3. Są one zgodne z rysunkiem wykonawczym tłoczyska.

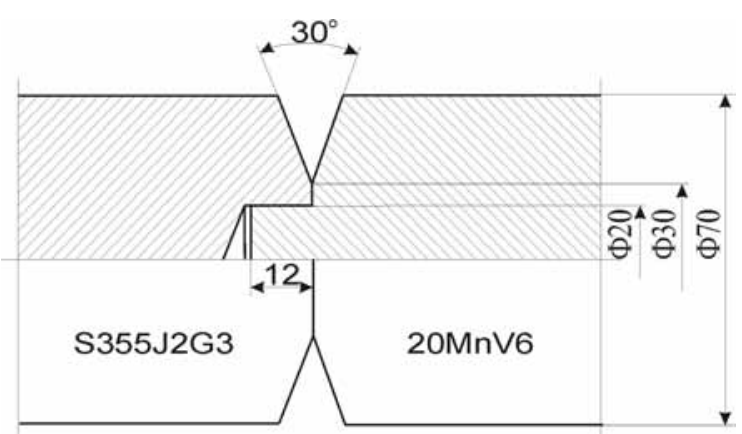

Rys. 3. Elementy złącza próbnego przygotowane do spawania Fig. 3. Elements of the test joint prepared for welding

Tablica I. Skład chemiczny oraz właściwości mechaniczne podstawowych i dodatkowych materiałów złączy próbnych

Table I. Chemical composition and mechanical properties of primary and secondary materials test joint

\begin{tabular}{|c|c|c|c|c|}
\hline \multirow{2}{*}{ 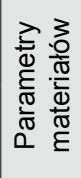 } & \multicolumn{2}{|c|}{ Materiał podstawowy } & \multirow{2}{*}{$\begin{array}{c}\begin{array}{c}\text { Materiał } \\
\text { dodatkowy }\end{array} \\
\text { E70C-6M }\end{array}$} & \multirow{2}{*}{$\begin{array}{c}\begin{array}{c}\text { Gaz } \\
\text { osłonowy }\end{array} \\
\text { M21 } \\
\text { PN-EN 439 }\end{array}$} \\
\hline & Stal S355J2G3 & Stal 20MnV6 & & \\
\hline 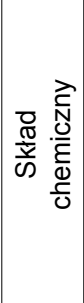 & $\begin{array}{c}\text { C-0,18; } \\
\mathrm{Mn}-1,41 ; \\
\mathrm{Si}-0,38 \\
\mathrm{P}-0,02 \\
\mathrm{~S}-0,01 \\
\mathrm{Cu}, \mathrm{Cr}, \mathrm{Ni} \\
\mathrm{Mo}<0,05\end{array}$ & $\begin{array}{c}\text { C-0,16-0,22; } \\
\text { Mn - 1,3-1,6; } \\
\text { Si - 0,1-0,35; } \\
\quad \text { P-0,3; } \\
\text { S-0,02-0,04; } \\
\text { V- } 0,08-0,15\end{array}$ & $\begin{array}{r}\text { C-0,06; } \\
\text { Mn-1,46; } \\
\text { Si - 0,66; } \\
\text { S- } 0,15 \\
\text { P- } 0,15\end{array}$ & $\begin{array}{c}18 \mathrm{CO}_{2}+ \\
82 \mathrm{Ar}\end{array}$ \\
\hline 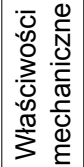 & $\begin{array}{c}\mathrm{R}_{\mathrm{eH}}=335 \mathrm{MPa} \\
\mathrm{R}_{\mathrm{m}}=470 \mathrm{MPa} \\
\mathrm{A}=32 \%\end{array}$ & $\begin{array}{c}\mathrm{R}_{\mathrm{eH}}=420 \mathrm{MPa} \\
\mathrm{R}_{\mathrm{m}}=550 \mathrm{MPa} \\
\mathrm{A}=18 \%\end{array}$ & $\begin{array}{c}\mathrm{R}_{\mathrm{eH}}=470 \mathrm{MPa} \\
\mathrm{R}_{\mathrm{m}}=550 \mathrm{MPa} \\
\mathrm{A}=28 \%\end{array}$ & \\
\hline
\end{tabular}




\section{Badania złączy próbnych i ich wyniki}

Ze złączy próbnych pobrano próbki do badań niszczących z miejsc określonych na rysunku 4 . Z każdego złącza pobrano próbki do prób rozciągania, łamania i twardości oraz badań makroskopowych. Maksymalna siła rozciągająca $(1000 \mathrm{kN})$ będącej do dyspozycji maszyny wytrzymałościowej okazała się za mała do rozerwania całego złącza próbnego. $Z$ tego powodu zdecydowano się na próbki do rozciągania o przekroju w postaci wycinka koła. Wyniki próby rozciągania podano w tablicy II, a przykładowe próbki po próbie rozciągania pokazano na rysunku 5. Złomy wszystkich próbek powstały $w$ obrębie spoiny. Pomimo to wyniki prób należy uznać za dodatnie, ponieważ pola przekrojów próbek $w$ miejscu spoin były mniejsze niż pól przekrojów poprowadzonych przez materiały podstawowe, jak również z tego powodu, że wyznaczone wytrzymałości na rozciąganie próbek w każdym przypadku są większe od wytrzymałości słabszego materiału podstawowego (tabl. I i II). Żeby to potwierdzić, pobrano dodatkowo ze złączy próbnych próbki o przekrojach kołowych, których pola przekrojów w obrębie spoiny i materiałów podstawowych były równe. W przypadku każdej rozciąganej próbki złom powstał poza spoiną, w stali S355J2G3.

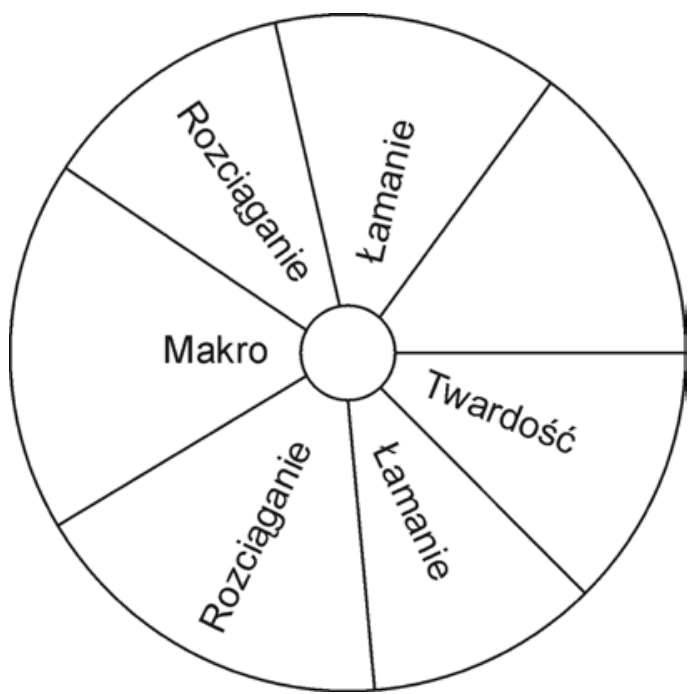

Rys. 4. Rozmieszczenie próbek do badań spoiny czołowej w złączu prętów

Fig. 4. Location of test samples in a butt weld joint with rods

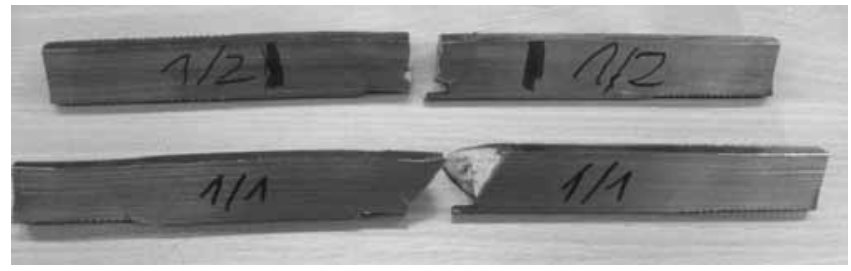

Rys. 5. Próbki po próbie rozciągania pobrane ze złącza 1

Fig. 5. Sample after tensile test taken from joint 1
Na próbkach do próby łamania nacinane są karby ułatwiające ich złamanie [6]. W przypadku próbek pobranych z próbnych złączy tłoczysk z karbem konstrukcyjnym takiej potrzeby nie było. Każda próbka złamała się w obrębie spoiny. O łatwości łamania tych próbek świadczą wartości kątów, przy których próbki złamały się (tabl. III). Na powierzchniach złomów nie stwierdzono niezgodności spawalniczych.

Podobnie jak próby rozciągania i łamania, również próba twardości dała wynik dodatni. Twardość złączy próbnych nie przekroczyła wartości 300 HV10 (rys. 6).

Zdjęcia makroskopowe wykonano dla czterech złączy próbnych. Tylko w przypadku jednego z nich, złącza nr 1 spawanego drutem zasadowym bez grzania wstępnego, nie stwierdzono niezgodności spawalniczych (rys. 7). Na pozostałych zgładach złączy stwierdzono lokalne niezgodności od strony grani. Przykładowe zdjęcie makroskopowe z taką niezgodnością spawalniczą pokazano na rysunku 8 . Negatywny wynik badań makroskopowych przyczynił się do wykonania kolejnych złączy próbnych, po wprowadzeniu zmian w procesie spawania. $\mathrm{Na}$ zdjęciach makrostruktur próbek pobranych z nowo wykonanych złączy próbnych tłoczysk nie stwierdzono niezgodności spawalniczych.

Tablica II. Wyniki próby rozciągania

Table II. The results of the tensile test

\begin{tabular}{|c|c|c|c|c|c|c|}
\hline$\sum \frac{\mathbb{N}}{\frac{N}{N}}$ & 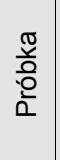 & $\begin{array}{c}\text { Drut/ } \\
\text { grzanie } \\
\text { wstępne }\end{array}$ & $\begin{array}{c}\text { Pole } \\
\text { przekroju } \\
\text { próbki } \\
\mathrm{S}_{\mathrm{o}}, \mathrm{mm}^{2}\end{array}$ & $\begin{array}{l}\text { Siła } \\
\mathrm{F}_{\mathrm{m}} \\
\mathrm{kN}\end{array}$ & $\begin{array}{c}\text { Wytrzymałość } \\
\text { na rozciąganie } \\
\mathrm{R}_{\mathrm{m}} \\
\mathrm{MPa}\end{array}$ & $\begin{array}{r}\text { Miejsce } \\
\text { złomu }\end{array}$ \\
\hline \multirow{2}{*}{1} & $1 / 1$ & \multirow{2}{*}{$\begin{array}{c}\text { zasadowy/ } \\
\text { nie }\end{array}$} & 497,2 & 275 & 553 & spoina \\
\hline & $1 / 2$ & & 526,2 & 300 & 570 & spoina \\
\hline \multirow{2}{*}{2} & $2 / 1$ & \multirow{2}{*}{$\begin{array}{c}\text { zasadowy/ } \\
\text { tak }\end{array}$} & 535,0 & 309 & 578 & spoina \\
\hline & $2 / 2$ & & 503,0 & 285 & 567 & spoina \\
\hline \multirow{2}{*}{3} & $3 / 1$ & \multirow{2}{*}{$\begin{array}{l}\text { rutylowy/ } \\
\text { nie }\end{array}$} & 517,5 & 288 & 557 & spoina \\
\hline & $3 / 2$ & & 485,5 & 280 & 577 & spoina \\
\hline \multirow{2}{*}{4} & $4 / 1$ & \multirow{2}{*}{$\begin{array}{l}\text { rutylowy/ } \\
\text { tak }\end{array}$} & 475,4 & 276 & 581 & spoina \\
\hline & $4 / 2$ & & 475,4 & 280 & 589 & spoina \\
\hline
\end{tabular}

Tablica III. Wyniki próby łamania

Table III. The results of the breaking test

\begin{tabular}{|c|c|c|c|}
\hline Nr złącza & Próbka & Kąt złamania, $^{\circ}$ & Miejsce złomu \\
\hline \multirow{2}{*}{1} & $1 / 1$ & 72 & spoina \\
\cline { 2 - 4 } & $1 / 2$ & 105 & spoina \\
\hline \multirow{2}{*}{2} & $2 / 1$ & 60 & spoina \\
\cline { 2 - 4 } & $2 / 2$ & 110 & spoina \\
\hline \multirow{2}{*}{3} & $3 / 1$ & 83 & spoina \\
\cline { 2 - 4 } & $3 / 2$ & 102 & spoina \\
\hline \multirow{2}{*}{4} & $4 / 1$ & 65 & spoina \\
\cline { 2 - 4 } & $4 / 2$ & 58 & spoina \\
\hline
\end{tabular}


Przy grani spoiny tłoczyska (rys. 1), a także złączy próbnych (rys. 3), w wyniku dużej różnicy pól przekrojów złącza pojawia się karb, w którym występuje spiętrzenie naprężeń, określone współczynnikiem kształtu $\alpha_{k}$ [7]. Współczynnik kształtu badanych złączy próbnych obliczono na podstawie rozkładu naprężenia normalnego wyznaczonego metodą elementów skończonych (rys. 9). Jego wartość obliczono jako iloraz naprężenia maksymalnego $\sigma_{\mathrm{m}}$ i naprężenia nominalnego $\sigma_{\mathrm{n}} \mathrm{w}$ badanym przekroju:

$$
\alpha_{k}=\frac{\sigma_{m}}{\sigma_{n}}=\frac{1890}{319}=5,9
$$

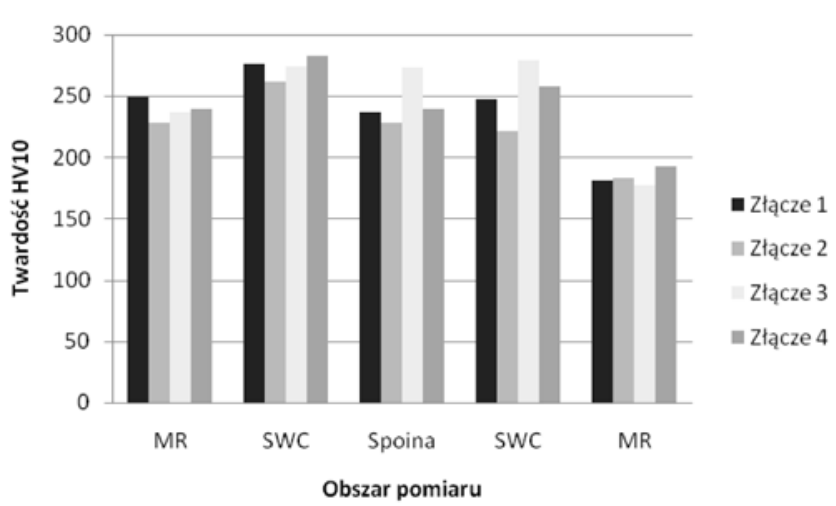

Rys. 6. Maksymalne wartości twardości próbnych złączy tłoczysk spawanych

Fig. 6. The maximum value of hardness test piston rod welded joints

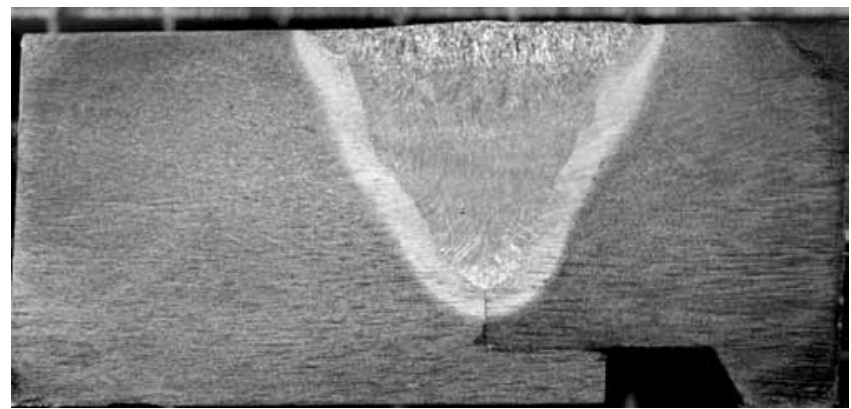

Rys. 7. Zdjęcie makroskopowe złącza $\mathrm{nr} 1$ spawanego drutem zasadowym bez grzania wstępnego

Fig. 7. Photo macroscopic joint no. 1 welded of alkaline wire without preheating

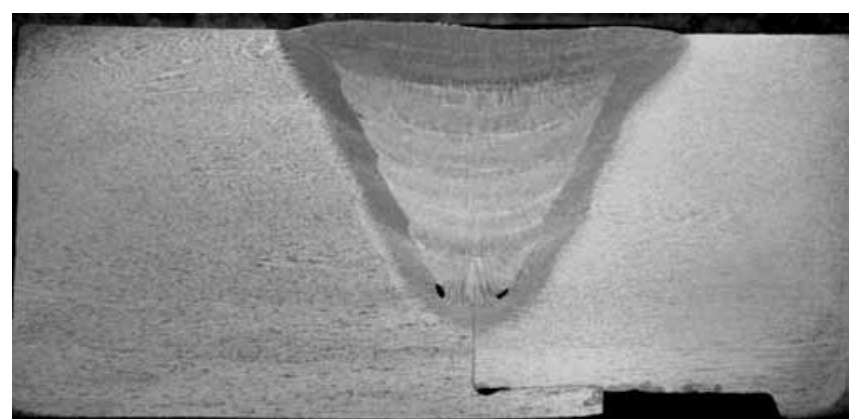

Rys. 8. Zdjęcie makroskopowe złącza nr 4 spawanego drutem rutylowym z grzaniem wstępnym

Fig. 8. Photo macroscopic joints no. 4 welded of rutile wire with preheating
Wartości współczynnika kształtu $\alpha_{k}$ dla zmian przekroju najczęściej spotykanych w budowie maszyn można wyznaczyć na podstawie wykresów zamieszczonych w [7]. Zamieszczone tam wykresy, dotyczące wałów pełnych i wydrążonych, opracowano jedynie dla przypadków, w których $\alpha_{k} \leq 3,8$. Można przyjąć, że w praktyce nie powinno projektować się wałów, dla których współczynnik kształtu ma wartości $\alpha_{k}>3,8$ oraz że przedmiotowe tłoczysko o większej wartości współczynnika kształtu $\alpha_{k}=5,9$ będzie charakteryzować się niską wytrzymałością zmęczeniową.

W złączach spawanych w wielu przypadkach początek rozwoju złomu zmęczeniowego następuje w spojeniu, gdzie powstały niepożądane zmiany struktury lub niezgodności spawalnicze. W celu sprawdzenia, czy w przypadku badanych złączy próbnych ich spojenie nie będzie miejscem początku złomu zmęczeniowego, pobrano z każdego złącza po jednej próbce (rys. 10). Wykonano na nich próbę zginania obrotowego. W każdym przypadku obciążenia miały takie same wartości. Złomy czterech próbek powstały nie w spoinie lub w jej pobliżu, ale w miejscu przejścia części chwytowej próbki, o średnicy $12 \mathrm{~mm}$, w część środkową zawierającą spoinę o średnicy $10 \mathrm{~mm}$, pomimo tego, że przejście z jednej średnicy w drugą było łagodne (promień zaokrąglenia $r=1 \mathrm{~mm}$ ).

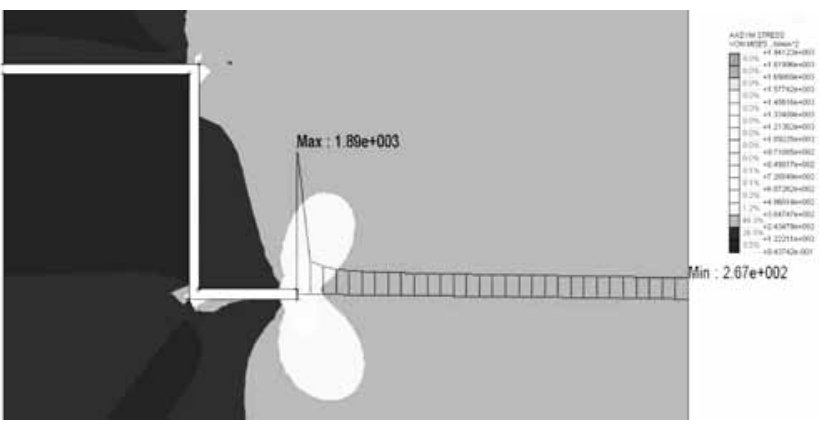

Rys. 9. Rozkład naprężenia normalnego na przekroju spoiny złącza próbnego

Fig. 9. Normal stress distribution on the cross-section of the weld joint test

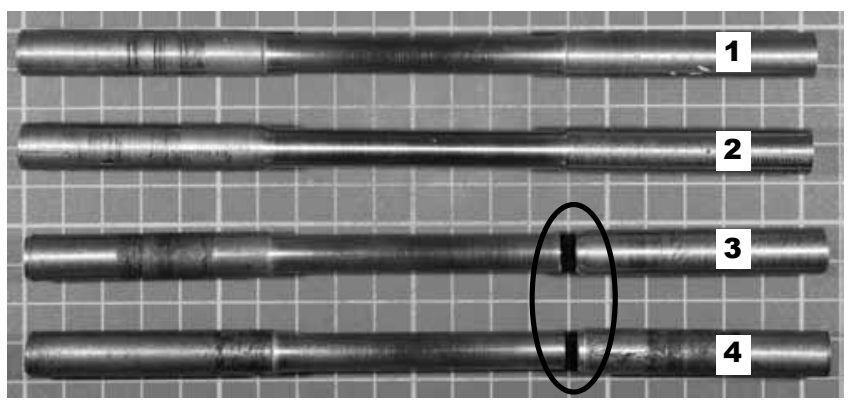

Rys. 10. Próbki do próby zmęczeniowej (1, 2 - przed próbą; 3, 4 - po próbie)

Fig. 10. Samples for fatigue test (1,2- before test; 3, 4-after test) 


\section{Podsumowanie}

$\mathrm{Na}$ podstawie wykonanych badań niszczących stwierdzono, że złącza próbne tłoczysk spawanych drutem rutylowym lub zasadowym, przy zastosowaniu lub nie - grzania wstępnego - mają zbliżone właściwości. Dla przykładu średnia wytrzymałość na rozciąganie próbek pobranych ze złącza spawanego drutem rutylowym z grzaniem wstępnym jest większa tylko o 4,1\% od odpowiedniej wytrzymałości próbek pobranych ze złącza spawanego drutem zasadowym bez grzania wstępnego. W takim przypadku o wyborze spawanego złącza tłoczyska do dalszych prac badawczych może zadecydować kryterium ekonomiczne.

Z przeprowadzonych badań można również wnioskować, że firma o odpowiednim poziomie technicznym może opracować i wdrożyć technologię spawania tłoczysk siłowników hydraulicznych, spełniającą wymagania stawiane w procedurze uznawania technologii spawania. Ostatecznie wszystkie badania niszczące złączy próbnych dały wynik pozytywny. Otrzymano spoiny o zadowalającej wytrzymałości. Postawiono jednak pytanie, czy badane tłoczyska, o zadanej postaci, pracujące pod obciążeniami zmiennymi, będą się charakteryzować odpowiednią wytrzymałością zmęczeniową. Wstępne badania zmęczeniowe tłoczysk spawanych dają odpowiedź negatywną i wskazują na konieczność dokonania zmian postaci tłoczysk, tak aby znacząco obniżyć wartość ich współczynnika kształtu $\alpha_{k}$.

\section{Literatura}

[1] www.orome.pl

[2] Pahl G., Beitz W.: Nauka konstruowania. WNT, Warszawa, 1984.

[3] www.skraw-met.pl

[4] www.hp.szczecin.pl

[5] PN-EN ISO 15614-1/2008: Specyfikacja i kwalifikowanie technologii spawania metali - Badanie technologii spawania - Część 1: Spawanie łukowe i gazowe stali oraz spawanie łukowe niklu i stopów niklu.
[6] PN-EN 1320:1999: Spawalnictwo - Badania niszczące spawanych złączy metali - Próba łamania.

[7] Niezgodziński M. E., Niezgodziński T.: Wzory, wykresy i tablice wytrzymałościowe. WNT, Warszawa,1996.

\section{Spotkania Spawalników w 2013}

\section{Warmińsko-Mazurska Biesiada Spawalnicza}

Olsztyn, 13.06.2013

\section{Dolnośląskie Sympozjum Spawalnicze}

Wrocław, 18.06.2013

\section{Szczecińskie Seminarium Spawalnicze}

Szczecin, 5.09.2013

\section{Pomorskie Spotkanie Spawalników}

Gdańsk, 17.10.2013

\section{Kieleckie Spotkanie Spawalników}

Kielce, 12.09.2013

Materiały konferencyjne zostaną opublikowane w numerze 6/2013 miesięcznika naukowo-technicznego Przegląd Spawalnictwa Szczegółowe informacje dotyczące uczestnictwa w spotkaniach zostaną podane w następnych numerach.

Termin nadsyłania materiałów do 30 kwietnia 2013 r. 